\title{
Waste as a resource in the United Kingdom: energy and sustainability
}

\author{
A. Arias-Garcia \& R. Lambourne \\ Waste Management Department, RPS Group PLC, UK
}

\begin{abstract}
In the world in which we live, where environmental issues are becoming increasingly important, seeing waste as a resource and recovering as much of its value as possible is an imperative. The aim of this paper is to offer a review of the waste management activities currently being undertaken in the United Kingdom (UK) and to provide a viewpoint on the reasons for technology choice. These reasons should be a key study focus to provide the tools for refining and improving practices. From an environmental viewpoint and looking at the global warming potential of any waste management solution it is clear that the choice should always aim to minimise greenhouse gas (GHG) emissions to the atmosphere. However, facilities are still being built where the choice is far from the best environmental solution. Among the factors affecting the technology choice, an important one is legislation, though it can still serve as a barrier to the successful integration of different mechanisms; in other cases the answer comes from technology limitations or economic balance. Analysing the outcomes and assessing the reasons for the technology choice in the UK is an essential exercise if progress towards a truly sustainable pattern of waste management is desirable. The authors have identified a number of issues that affect waste management in the UK namely the implementation of the Landfill Directive, the Waste Incineration Directive, renewable energy incentives and the unproven status of some technologies. The UK market represents a great opportunity for European technology providers and other sector stakeholders. However, understanding the UK business model is essential. This analysis could help European businesses that are achieving excellence in other countries to find the appropriate pathways to successfully bring the best solutions to the UK.

Keywords: waste, energy, renewable, sustainability, UK, policy, efficiency.
\end{abstract}




\section{Waste arising and management in the UK}

Sustainable waste management is high on the political agenda and includes issues of sustainability, waste growth and public concern over proximity to proposed waste treatment facilities as well as GHG emissions.

The UK produces around 330 million tonnes of waste annually - a quarter of which is from households and business. The rest comes from commercial and industrial, construction and demolition, sewage sludge, farm waste, spoils from mines and dredging of rivers (fig. 1). The UK is making progress towards the goals of the waste hierarchy and there is a steady trend towards reducing landfill and increasing recycling.

In 2006/7 local authorities (LAs) in England collected 29.1 million tonnes of waste from household collections and civic amenity sites, according to estimates released by the Department of Food and Rural Affairs (Defra). Of that, household waste accounted for 25.9 million tonnes (89\%). The proportion, which was recycled or composted, rose from $27.1 \%$ in $2005 / 6$ to $30.7 \%$ in $2006 / 7$. The percentage, which ended up in landfill, fell from $62 \%$ (17.9 million tonnes) in $2005 / 6$ to $58 \%$ (16.9 million tonnes) in $2006 / 7$.

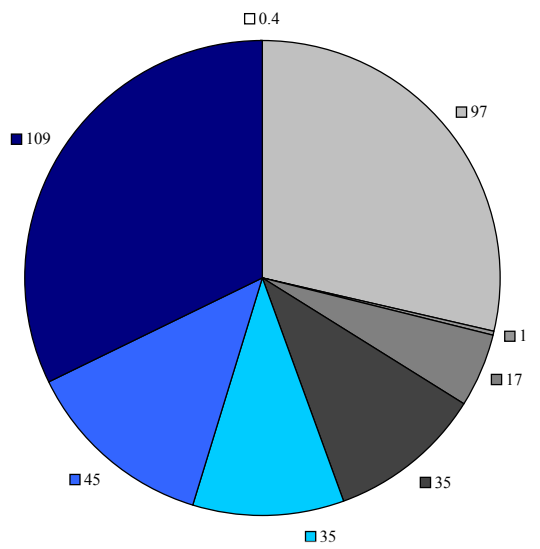

Figure 1: Estimated total UK annual waste arisings (million tonnes) by sector 2002/2003. Source: Derived from data published by Defra [2].

LAs control the primary supply of municipal solid waste (MSW), often under a two-tier system. In England waste disposal or treatment contracts are let by the Waste Disposal Authorities (WDAs), which are mainly the County Councils, with the District Councils being responsible for collection including kerbside recycling. Unitary Authorities and Metropolitan Districts are responsible for collection and disposal as are the local authorities in Wales and Scotland.

The last waste survey encompassing commercial and industrial (C\&I) waste was in 2002-2003. C\&I waste in England accounted for 68 million tonnes (fig. 2) with 38 million attributable to industry (of which 13 million tonnes was landfilled) and 30 million to commerce (of which over 14 million tonnes went to landfill). 
C\&I waste can include paper, card, metals and scrap equipment, mineral wastes and residues. It is produced by the manufacturing industry, wholesale and retail, catering, educational and administrative sectors.

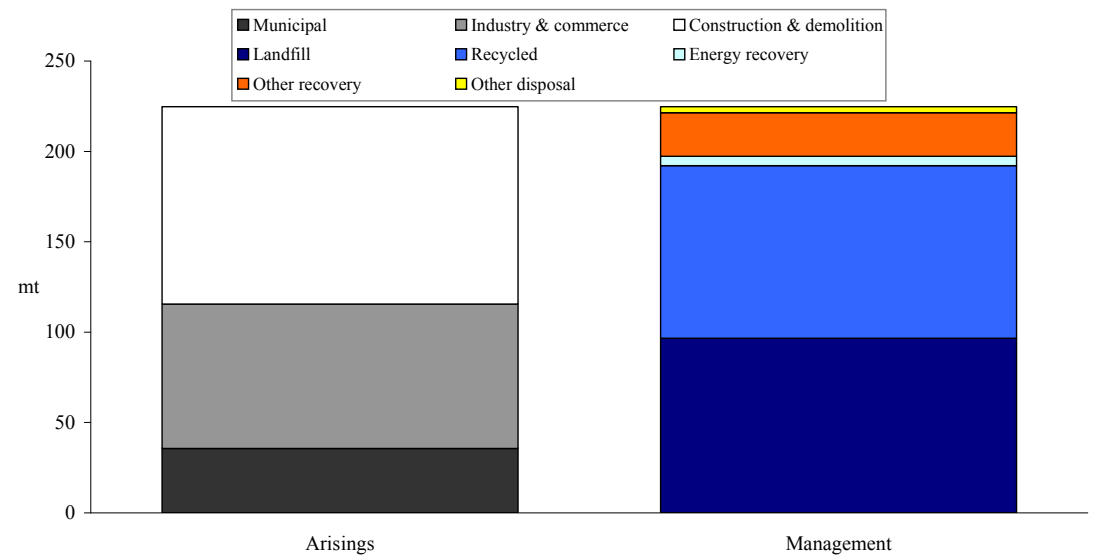

Figure 2: Arisings and management of waste from municipal and commercial and industrial sources 2002/3 Source: Adapted from data published by Defra [2].

Looking at fig. 3 and fig. 4, it can be seen that the individual sector that produced the most waste was the retail sector (commercial), which generated 13 million tonnes followed by food drink and tobacco (industrial), which generated 7 million tonnes.

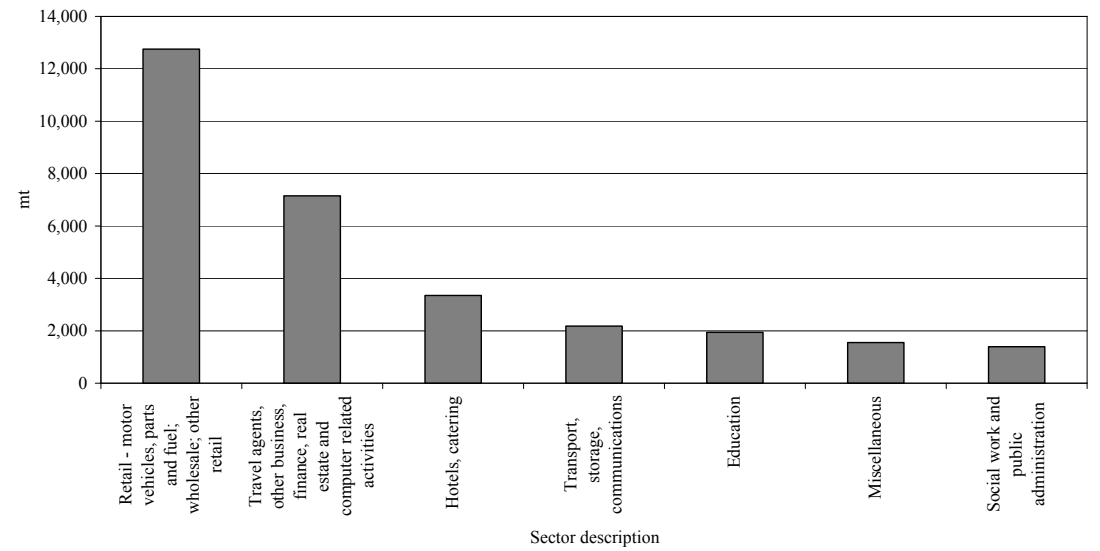

Figure 3: Commercial waste arisings by business sector. Source: Derived from data published by Defra [2]. 
Commercial sector waste contracts benefit from straightforward negotiations in contrast to the lengthy local authority procurement process. However, depending on the nature of the commercial waste, it may be that treatment business will still have to enter into a contract with a fuel producer and/or local authorities.

The key issue in sourcing C\&I waste will be the length of contracts available. Any facility to process C\&I waste arisings will probably have to contract on the basis of short term deals or even the spot market where price is very competitive.

To date, as there have not been any target requirements for C\&I waste, virtually all material ends up in landfill as this has represented the cheapest option. However with the increasing price of landfill and Landfill Tax, it is considered likely this source of material will become increasingly attractive.

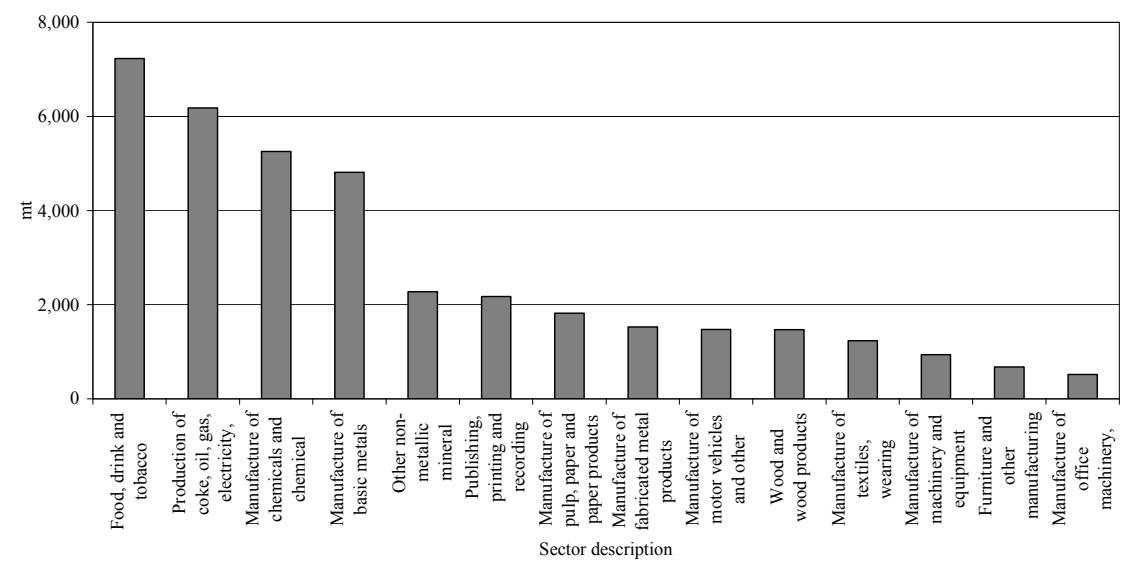

Figure 4: Industrial waste arisings by business sector. Source: Derived from data published by Defra [2].

\section{Energy usage in the UK}

In the UK the primary demand of energy in 2006 was 244.0 million tonnes of oil (10 million TJ and 3 million GWh). Total final consumption in 2006, which includes non-energy use of fuels, was 169.6 million tonnes of oil ( 7 million TJ and 2 million GWh). Final energy consumption in 2006 was mainly accounted for by the transport sector $(35 \%)$, the domestic sector $(27 \%)$, the industrial sector $(19 \%)$, the commercial sector $(6 \%)$ and non-energy use (7\%) [2].

The main fuels used by final consumers in 2006 were petroleum products (48.5\%), natural gas (31.5\%) and electricity (17.5\%). Of the petroleum products consumed by final users, $13.5 \%$ was for non-energy purposes; for natural gas $1.5 \%$ was consumed for non-energy purposes. 
In 2006, the main industrial groups consumed 32.6 million tonnes of oil, ( 1 million TJ or 0.4 million $\mathrm{GWh}$ ). The largest consuming groups were chemicals $(18 \%)$, metal products, machinery and equipment $(12.5 \%)$, food, beverages and tobacco $(11.5 \%)$, iron and steel and non-ferrous metals $(9 \%)$, mineral products $(8 \%)$, and paper, printing and publishing $(7 \%)$. The figures are illustrated in fig. 5 .

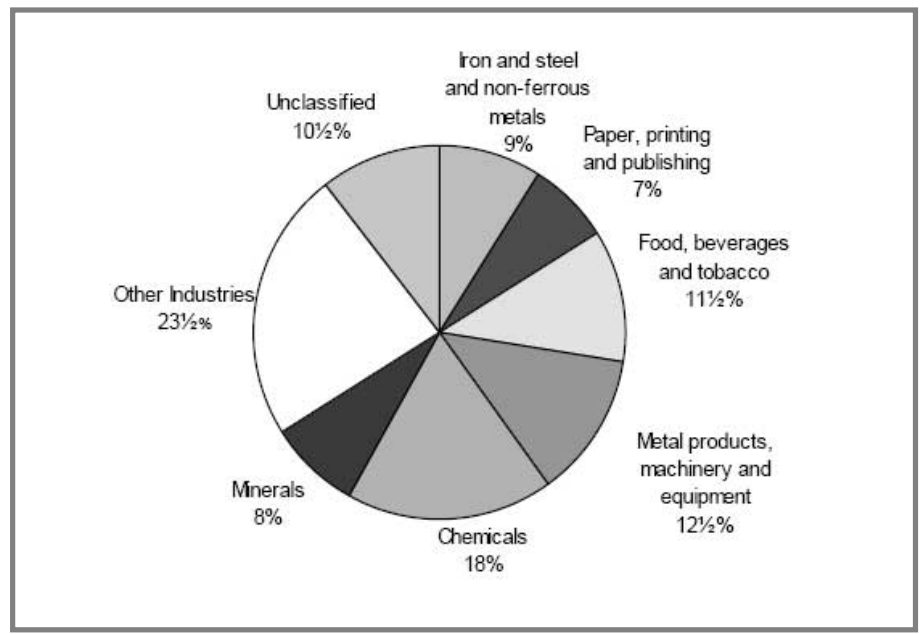

Figure 5: Energy consumption by main industrial groups 2006. Source: Department for Business Enterprise and Regulatory Reform [2].

\section{So why is it so important to relate both?}

In March 2008 the Cabinet Office of the United Kingdom published the report "The National Security Strategy of the United Kingdom" in which climate change and competition for energy are among the factors discussed. The report describes climate change as potentially the greatest challenge to global stability and security. In terms of energy, it states that on present projections global energy demand will be more than $50 \%$ higher in 2030 than today [1].

UK statistics show that in 2006, total carbon dioxide $\left(\mathrm{CO}_{2}\right)$ emissions were 554.5 million tonnes. $90 \%$ of this total was accounted for by three sectors, business, transport and residential, which represented $35 \%, 28 \%$ and $27 \%$ of the total, respectively. Of these sectors, there was an increase of $1.4 \%$ in business emissions, from 193.4 million tonnes in 2005 to 196.1 million tonnes in 2006, but little change in residential or transport emissions.

Total methane $\left(\mathrm{CH}_{4}\right)$ emissions in 2006 were 2339.8 thousand tonnes. $41 \%$ of these emissions were from waste management and $38 \%$ from agriculture. Of these major contributing sectors, there was a $1.4 \%$ increase in agricultural emissions, from 878 thousand tonnes in 2005 to 890 thousand tonnes in 2006, but little change in emissions from waste management.

Emissions of nitrous oxide $\left(\mathrm{N}_{2} \mathrm{O}\right)$ were 123.5 thousand tonnes in 2006 , a $3.7 \%$ decrease from 2005 levels. Emissions from agriculture, which accounted for $68 \%$ 
of total emissions on an end-user basis in 2006, fell by $4.6 \%$ between 2005 and 2006. Emissions from the other major contributing sector, transport, were 19.0 thousand tonnes in 2006 ( $15 \%$ of total emissions), a 2.0\% increase on 2005 levels.

Fig. 6 shows the UK emissions of $\mathrm{CO}_{2}, \mathrm{CH}_{4}$ and $\mathrm{N}_{2} \mathrm{O}$ by source. The plot has mixed units so all emissions can be appreciated. It can be seen that waste management and energy can play an important part in reducing GHG.

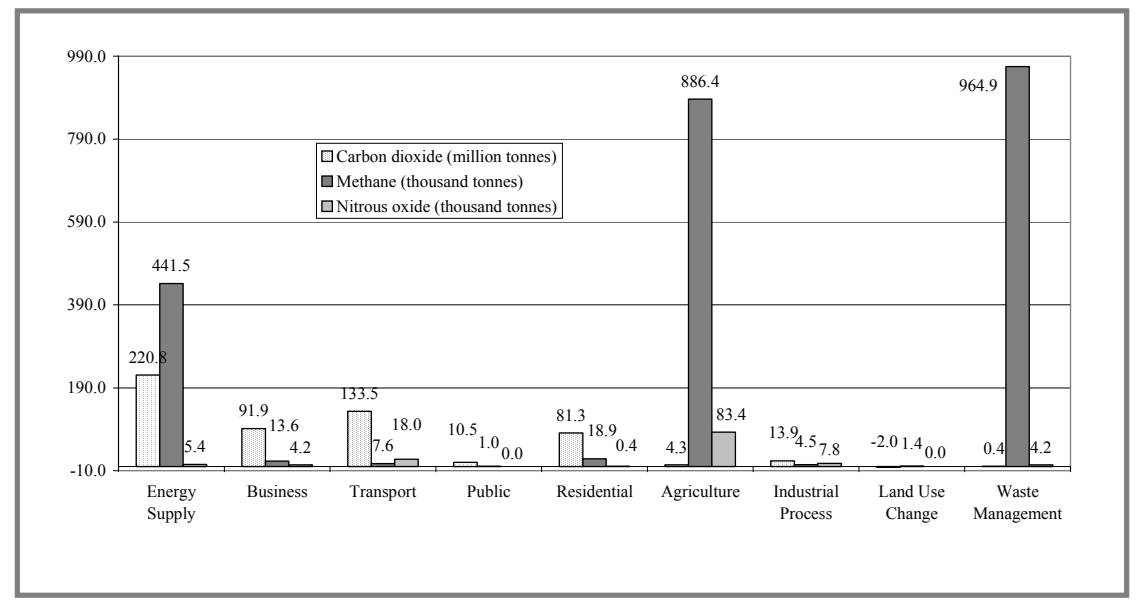

Figure 6: UK emissions of carbon dioxide, methane and nitrous oxide by source. Source: Derived from data published by Defra [6].

Fig. 6 clearly shows that reducing the amount of waste going to landfill could contribute significantly towards the reduction of GHG emissions. Indeed disposal to landfill is the last option in the waste hierarchy.

The waste hierarchy provides the basic steering framework of waste policy. The existence of a clear priority of reuse and recycling over the use of waste as an energy source is essential. Reuse and recycling avoids the use of energy and new materials.

But even after reuse and recycling there is a residual that needs to be dealt with. The Defra waste hierarchy (fig. 7) includes composting at the same level as recycling. Composting will deal with some of the organic fraction of the residual. However, a significant fraction of material organic and non-organic will remain that will require treatment.

Energy-from-waste (EfW) refers to any waste treatment that creates energy from a waste source that would have otherwise been landfilled. Some EfW processes result in usable fuel products, such as methane, methanol, ethanol or synthetic fuels upon completion of the process.

Generally energy can be recovered from waste by thermal (combustion, gasification or pyrolysis) or biological treatments (anaerobic digestion). There is also a type of Mechanical Biological Treatment (MBT) plant where the output can be used as a fuel and therefore recover energy from it. This fuel can be called Solid Recovered Fuels (SRF) or Refuse Derived Fuels (RDF) depending on whether it 
is made to European Standards or it is simply fuel derived from nonhazardous waste that has had some form of processing. The market for SRF is not yet established in the UK but it is growing. It is a material that is of interest to a number of industries due to its quality as a fuel combined with its high biomass content.
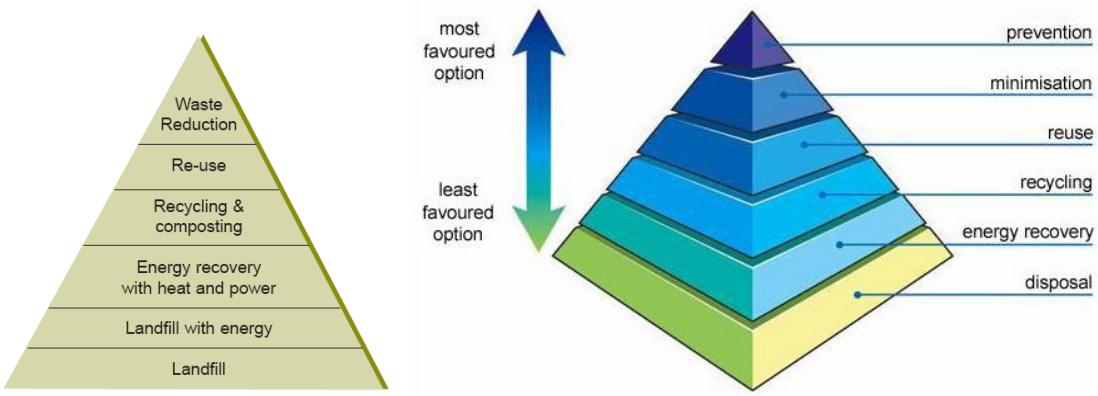

Figure 7: Waste hierarchy from Defra and Waste Framework directive. Source: Defra and Waste framework directive.

Environmental organisations like Friends of the Earth focus on phasing-out residual waste and agree with generating energy from waste via biological treatment but not via thermal treatment (on the basis, among others, that combustion creates GHG and other pollutants that cause health problems). They believe that the UK needs small-scale modular technologies to maximise removal of recyclables and to remove the biological activity of what remains prior to use in low-grade land treatment or disposal to landfill.

It cannot be disputed that thermal treatment creates $\mathrm{GHG}$, as in principle, combustion is the conversion of hydrocarbons into $\mathrm{CO}_{2}$ and water. However one would expect the Waste Incineration Directive to be robust enough to prevent any waste combustion facility from causing health problems - and if this is not the case, surely the Directive should be made stronger. On the other hand, if the energy recovered from waste is replacing energy obtained from fossil fuels why put the waste in the ground?

In terms of electricity generation, conventional EfW plants i.e. incinerators that produce electricity-only are inefficient plants - their efficiency rate of $24 \%$ compares with $38 \%$ from a modern coal-fired power station and $50 \%$ from a modern gas-fired power station. However, in Europe plants tend to use also the heat produced. The thermal utilisation is therefore typically $50-60 \%$. In addition there are examples of innovative process design like the Zabalgarbi plant in Bilbao where the efficiency achieved is $44 \%$. Of course there are barriers (which will be discussed later in the paper) to the implementation of these types of facilities as well as the use of heat, but perhaps government policy makers should re-examine the barriers and propose mechanisms for overcoming them.

In the UK almost half of all $\mathrm{CO}_{2}$ emissions arise from the use of heat. That is energy used for space and water heating, industrial process heating, industrial 
drying and similar purposes. Therefore, if long-term reductions in carbon emissions are to be delivered, how heat is produced has to be looked at.

Power stations are burning a material that has been in the ground for millions of years and is, in human timescales, non-renewable. Assuming electricity is generated from waste with the same or higher efficiency than from coal/gas as part of an integrated waste management policy where completion of the hierarchy's initial steps are ensured, what would be the issue with EfW?

The discussion so far leads to a simple conclusion. The mitigation of GHG emissions from waste and its contribution towards reducing GHG emissions in general must be addressed in the context of integrated and sustainable waste management practice supported by a strong policy framework.

\section{How much energy is contained in waste and how much is the UK already recovering?}

According to the figures presented in this paper 16.9 million tonnes of household waste was landfilled in England in 2006/2007. The figures for C\&I waste are from $2002 / 2003$ (but there is no indication that the amounts have reduced significantly) with 13 million tonnes of industrial and 14 million tonnes of commercial landfilled at the time. Table 1 presents the energy content of some waste streams.

Table 1: Energy in waste. Source: EC RDF, current practice and perspectives.

\begin{tabular}{|c|c|c|c|c|c|}
\hline Material & $\mathrm{CV}(\mathrm{MJ} / \mathrm{Kg})$ & Material & $\begin{array}{l}\mathrm{CV} \\
(\mathrm{MJ} / \mathrm{Kg})\end{array}$ & Material & $\begin{array}{l}\mathrm{CV} \\
(\mathrm{MJ} / \mathrm{Kg})\end{array}$ \\
\hline Tyres & $28.5-35$ & $\begin{array}{c}\text { Animal } \\
\text { waste }\end{array}$ & $16-17$ & $\begin{array}{c}\text { Commercial } \\
\text { waste }\end{array}$ & $16-20$ \\
\hline Plastics & $29-40$ & $\begin{array}{c}\text { Source } \\
\text { separated } \\
\text { waste }\end{array}$ & $20-23$ & $\begin{array}{c}\text { RDF from } \\
\text { industrial } \\
\text { waste }\end{array}$ & $18-21$ \\
\hline Waste wood & $\begin{array}{c}15-17(10- \\
15 \% \text { residual } \\
\text { water })\end{array}$ & $\begin{array}{c}\text { RDF from } \\
\text { MSW }\end{array}$ & 13 & $\begin{array}{c}\text { Demolition } \\
\text { waste }\end{array}$ & $14-15$ \\
\hline Paper & $12.5-22$ & $\begin{array}{c}\text { Untreated } \\
\text { MSW }\end{array}$ & $8-11$ & Waste Oil & 35 \\
\hline Paper sludge & 8.5 & SRF & $5-25$ & Solvent & 27 \\
\hline $\begin{array}{c}\text { Dried sewage } \\
\text { sludge }\end{array}$ & $16-17$ & $\begin{array}{c}\text { Household } \\
\text { waste }\end{array}$ & $12-16$ & & \\
\hline
\end{tabular}

If simple calculations are applied to the figures, it could be easily stated that, out of the 16.9 million tonnes of household waste, if $25 \%$ of it would be treated via thermal treatment with an average efficiency of $50 \%, 4690 \mathrm{GWh}$ would be obtained. Performing the same calculations to C\&I waste, it could be seen that $9375 \mathrm{GWh}$ could be recovered making a combined $14069 \mathrm{GWh}$ which represents approximately $4 \%$ of all the industrial energy consumption. 
Table 2 provides a summary of the combined capacity and energy produced from waste in the UK. Fig. 8 provides a map with a geographical representation of the waste treatment facilities in the UK.

Table 2: Summary of waste treatment facilities in the UK. Source: RPS.

\begin{tabular}{|c|c|c|c|c|c|}
\hline Technology & $\begin{array}{c}\text { Number of } \\
\text { Facilities }\end{array}$ & $\begin{array}{c}\text { Combined } \\
\text { Capacity }\end{array}$ & $\begin{array}{c}\text { Electricity } \\
\text { produced } \\
\text { (MWh) }\end{array}$ & $\begin{array}{c}\text { Heat } \\
\text { recovered } \\
(\mathrm{MWh})\end{array}$ & $\begin{array}{c}\text { Average } \\
\text { efficiency \% }\end{array}$ \\
\hline Incineration & 22 & 4403 & 309 & 90 & 35 \\
\hline ATT & 6 & 363 & 50 & 1.5 & 39 \\
\hline AD & 6 & 233 & 6 & 3 & NA \\
\hline
\end{tabular}

The data presented highlight the need for more treatment facilities in the UK. There are a number of LAs that are in the procurement process and others which have just announced their preferred bidder. In addition, there is an important opportunity deal with C\&I waste in a sustainable way.

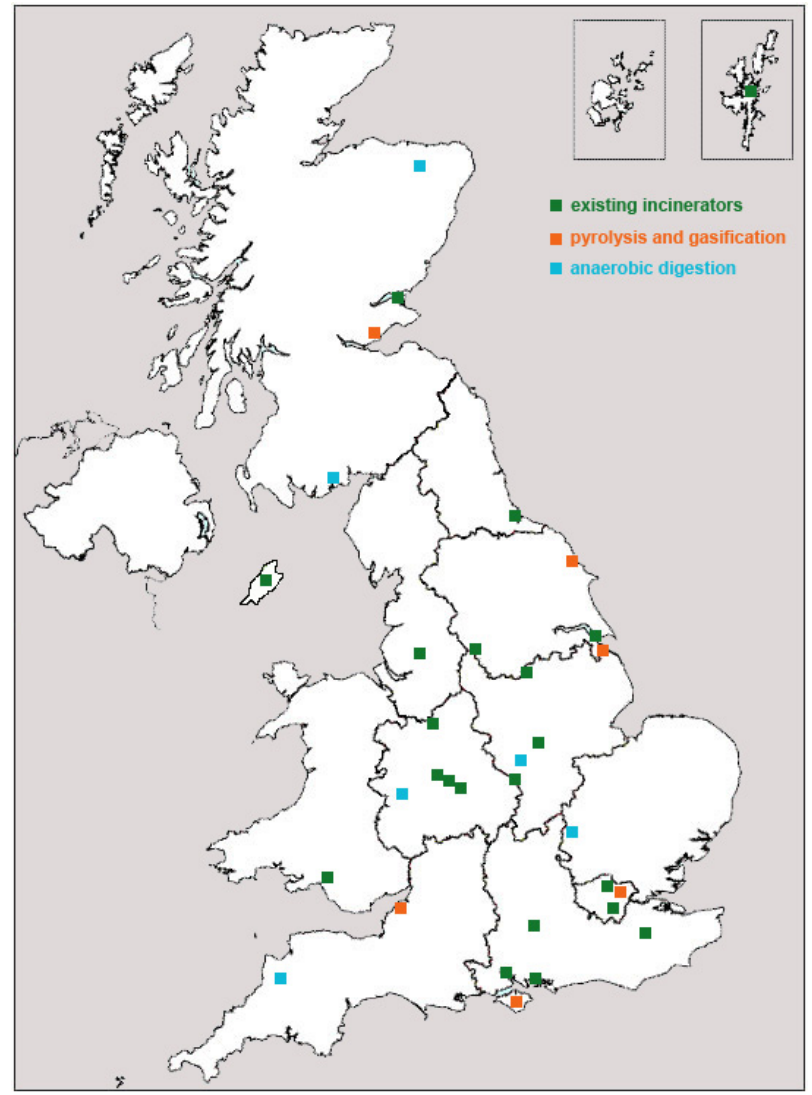

Figure 8: Waste treatment facilities in the UK. Source: RPS. 
Growing numbers of UK local authorities are now selecting EfW as the most cost-effective and practical solution for treating residual waste. However some of the new proposals do not incorporate heat recovery as an option or consider efficiency as the first priority.

Drivers are different for MSW projects compared to C\&I projects. In terms of MSW projects, the main driver is the diversion of biodegradable material to landfill followed by economic outcome. However, when it comes to C\&I waste, it is the economic outcome that prevails. Environmental impact also plays a part in the procurement/contractual process but generally does not exert enough influence to determine the technology of choice. If sustainability was the first priority, in an ideal society, it might be able to achieve the Friends of the Earth aim of phasing out residual waste. However, in the present society with sustainability as the first priority, work could be done towards an integrated sustainable solution where waste management, energy generation and combating climate change would be jointly assessed.

\section{Barriers to increasing efficiency}

There are a number of barriers to this goal and the following paragraphs discuss some of them. The order of presentation implies no hierarchy of importance.

The first one is economic viability. For a project to be successful it has to be economically viable to secure the support of the financial institutions. Unfortunately there are not sufficient economic incentives to support facilities that are more costly and could achieve above-average levels of efficiency. This point links directly with legislation. As seen in table 3, there are a number of mechanisms that have been created to encourage sustainability in the waste and energy sector. However the UK has to resolve an anomaly that exists for those supplying renewable energy. Currently, a business providing renewable electricity will be rewarded through the Renewables Obligation Certificates (ROCs) as long as the electricity can feed the National Grid. Biogas and biomethane do not enjoy the same privileges and the department for Business Enterprise and Regulatory Reform (BERR) is currently studying potential mechanisms to support the development of renewable heat.

And finally project risk both to secure the material and to secure the energy user. The barriers seem to be the lack of strategic partnership at a regional level to bring together the material and reduce the risk for the operator and the finance provider. In terms of heat the threat lies in securing the user throughout the life of the project. This risk has to be minimised if heat is ever going to be utilised.

There are two recent mechanisms that might help reducing this risk by encouraging/helping energy users and waste facilities to include heat in their search/production of renewable energy. The first one is the Carbon Reduction Commitment and the second is the establishment of joint waste authorities in England.

Announced in the Energy White Paper 2007, the Carbon Reduction Commitment Scheme (CRC) applies mandatory emissions trading to cut carbon emissions from large commercial and public sector organisations. It covers around 
$10 \%$ of the UK economy-wide emissions and provides incentives for organisations to increase energy efficiency. The scheme started in January 2010 with a three-year introductory phase featuring simple fixed-price sales of allowances. From 2013, there is a Government imposed cap on the number of allowances and all allowances will be sold each year via an auction, a world-first for this type of scheme [3].

Table 3: Policy instruments in the UK and European Union (EU). Source: RPS.

\begin{tabular}{|l|l|l|}
\hline \multirow{5}{*}{ Waste } & EU & UK \\
\hline \multirow{5}{*}{ Energy } & $\begin{array}{l}\text { Landfill directive } \\
\text { Thematic Strategy } \\
\text { Waste Framework Directive } \\
\text { Soil Directive } \\
\text { CEN 343 Standards } \\
\text { Waste Incineration Directive }\end{array}$ & $\begin{array}{l}\text { Waste Strategy for England 2007 } \\
\text { UK Biomass Strategy } \\
\text { Landfill Tax }\end{array}$ \\
\hline \multirow{5}{*}{ Environment } & $\begin{array}{l}\text { Co-generation Directive } \\
\text { Biomass Directive } \\
\text { Biofuels Directive } \\
\text { Renewable Energy Directive } \\
\text { Proposal for a Directive on the } \\
\text { promotion of the use of energy } \\
\text { from renewable sources }\end{array}$ & $\begin{array}{l}\text { Renergy White Paper } \\
\text { Obligation }\end{array}$ \\
& $\begin{array}{l}\text { Eeat Obligation } \\
\text { EUETS } \\
\text { Green Paper: Adapting to climate } \\
\text { change in Europe - options for } \\
\text { EU action } \\
\text { Climate action and renewable } \\
\text { energy package }\end{array}$ & $\begin{array}{l}\text { Climate Change Programme } \\
\text { Carbon Emissions Reduction } \\
\text { Target } \\
\text { Carbon Reduction Commitment } \\
\text { Climate Change Bill } \\
\text { Planning Policy Statement. } \\
\text { Planning and Climate change }\end{array}$ \\
\hline
\end{tabular}

On the other hand, in March 2008, the UK government launched a consultation regarding proposals for the establishment of joint waste authorities in England. Joint working on waste is becoming increasingly important in the drive for more efficient and sustainable waste management. While there is already a wide range of active waste partnerships across the country, one of the key barriers to joint working is the limited legal basis for joint working arrangements. This can create difficulties when authorities are dealing with the private sector. Allowing authorities to enter into a legal commitment to work together on a statutory basis provides greater certainty to potential finance providers and contractors [4].

\section{Additional factors influencing the change}

Historically landfill was relatively cheap and benefited from low processing costs. However, landfill tax has increased significantly in recent years ( $£ 24$ per tonne in $2007 / 08$ ) and will increase at $£ 8$ per tonne per year from $2008 / 9$ to $2010 / 11$. Furthermore, there is a shortage of landfill capacity in some parts of the UK, which means that landfill gate fees are also increasing. 
Another major influence is the fact that a consistently high world oil price will affect the economics of EfW to such an extent as to overcome the economic risk. As the price of oil reaches new highs, one can see EfW projects extracting every single MWh from the energy in the waste and overcoming the current economic barriers associated with combined heat and power installations and other innovative projects.

Finally, the time will come when the mechanisms to support renewable energy will include heat. This would be coupled with other mechanisms where heat users will be encouraged (through carbon policies) to make use of renewable heat instead of producing new.

Legislation is moving fast and the UK and EU are making every effort to integrate policies and provide the mechanisms towards sustainable waste management. The UK is a market with plenty of opportunities, which is moving quickly towards sustainable waste management. The decisions made today need to be forward-thinking enough to take advantage of the change in drivers and the future integration of policies.

\section{References}

[1] Cabinet Office, The National Security Strategy of the United Kingdom, Crown, 2008.

[2] Department for Business Enterprise and Regulatory Reform, Digest of United Kingdom Energy Statistics 2007, National Statistics, 2007.

[3] Department for Food and Rural Affairs, Action in the UK-Carbon Reduction Commitment, http://www.defra.gov.uk, 2008.

[4] Department for Food and Rural Affairs, Consultation on draft Regulations and draft guidance for proposals for establishing Joint Waste Authorities in England, http://www.defra.gov.uk/corporate, 2008.

[5] Department for Food and Rural Affairs, e-Digest Statistics about: Waste and Recycling, http://www.defra.gov.uk/environment/statistics, 2008.

[6] Department for Food and Rural Affairs, e-Digest Statistics about: Climate Change, http://www.defra.gov.uk/Environment/statistics, 2008. 